\title{
小土被りトンネル掘削時におけるトンネル脚部および 地表面沈下対策工に関する実験的検討
}

\author{
崔 瑛 ${ }^{1}$, 岸田 潔 ${ }^{2}$, 木村 亮 $^{3}$
}

1 京都大学 $\cdot$ 大学院工学研究科 博士課程

2 京都大学・工学研究科 准教授

3 京都大学・産官学連携センター 教授

\section{概 要}

地形的・線形的な制約により, 小土被りの未固結地山でのトンネルの建設が数多く進められている。これらの建設現 場では, 地表面とトンネルが同時に同程度沈下寸るとも下がり現象が報告されており, 沈下の抑制が重要な課題となる。 その対策工法のひとつとしてサイドパイル補助工法が用いられ効果を発揮しているが, そのメカニズムについては未解 明の部分が多い。本研究では, 模型実験および模型実験に対する数值解析を実施し, 長さおよひ設置間隔がサイドパイ ルの地表面沈下抑制効果に及ぼす影響について検討を行い, そのメカニズムの解明および各パラメータの選定方法の検 討を行った。結果として, サイドパイルはせん断補強効果および荷重再配分効果による沈下抑制効果を発揮し, とも下 がり現象を軽減することが確涩された。

キーワード：トンネル掘削，小土被り，地表面沈下，模型実験，数值解析

\section{1.はじめに}

土被りの小さい未固結地山では, 開削工法やシールド工法 によりトンネルが建設されてきたが, 近年では支保パターン の多様化や様々な補助工法の開発により, 土被りの小さい未 固結地山においても NATM 工法が採用されるようになって いる。例えば，東北新幹線の八戸〜七戸間のトンネル工事区 間 1)では，地形的な制約や線形的な制約により，NATM 工法 を用いて小土被りの未固結地山でのトンネル工事が進めら れている。これらの建設現場では, 図-1 (a)に示す地表面と トンネルがほぼ同程度沈下するとも下がり現象が報告され ており, 沈下の抑制が重要な課題となっているが, その発生 メカニズムは十分に解明されていない。

現状では，「脚部の沈下を抑制すれば地表面の沈下も収ま るだろう」との考えから，脚部補強工の一種であるサイドパ イル工が用いられている。図-1 (b) ${ }^{1)} に$, サイドパイル工の実 際の施工例を示す。この工法は, 鋼製支保工建て込み直後に パイルを水平方向に圧入打撃し，そのパイルと両側の鋼製支 保工に渡した補強プレートに溶接した後, 吹付けコンクリー 卜を施工することで，鋼製支保工，パイル，補強プレートを 一体化させるものである。サイドパイル工は実施工に使用さ れており, その効果が報告されている ${ }^{1)}$ が，その作用メカニ ズムについてはまだ十分に解明されていない。

山田ら ${ }^{2)}$ は, 数值解析手法を用いてとも下がり現象を再現
し，その対策として，長尺鏡ボルトによる鏡面安定対策と注 入式フォアボーリングによる天端補強対策を選定し, 実現場 にてその効果の確認を行っている。また, 福島ら ${ }^{3), 4)}$ は, ボ ルト系補助工法として斜めボルト, 鏡止めボルトなどの研究 を, 大川ら ${ }^{51}$ は, 鋼管系補助工法としてパイプルーフに関す る研究を実施している。サイドパイル工に関する研究は, 北 川ら ${ }^{6,7)}$ が逆 $\mathrm{T}$ 字型の断面を持つ覆工モデルでトンネルの脚 部をモデル化し, サイドパイルの地表面沈下抑制効果につい て模型実験を通じて検討を行っているが, 他はあまり実施さ れていないのが現状である。

そこで本研究では, サイドパイル工の作用メカニズムを解 明するため, 北川ら ${ }^{6), 7)}$ の覆工模型実験に改良を加えた実

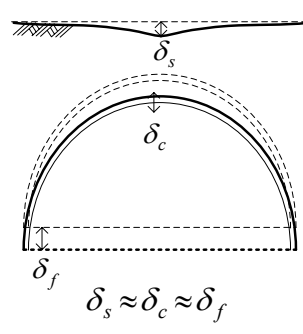

(a) とも下がり現象

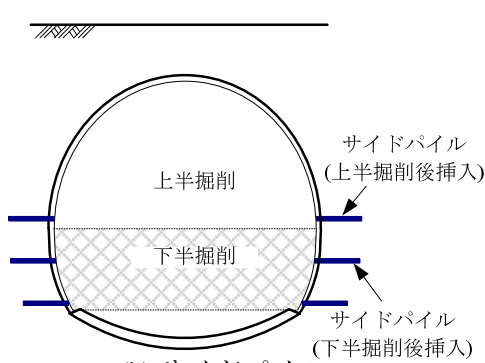

(b) サイドパイル
図-1とも下がり現象およびサイドパイル工のイメージ図 ${ }^{11}$

験を行い, さらに模型実験に対する数值解析を実施した。実 際には, 模型実験でとも下がり現象の再現を行い, サイドパ 
イルの長さおよび設置間隔が地表面沈下抑制効果に及ぼす 影響について検討を行う。さらに, 模型実験に対する数值解 析を通じて, 地盤およびサイドパイルの力学挙動について検 討した。

\section{2. 模型実験}

\section{1 モデル化の概要}

模型実験でとも下がり現象を再現するには，トンネル掘削 とそれに伴う地表面沈下および同程度のトンネル沈下を同 時に表現しなければならない。掘削に伴う応力解放と地盤条 件の組合せがとも下がり現象を発生させると考えるが，これ らの境界条件・地山条件を忠実に表現することは極めて困難 である。そこで本研究では, 問題を単純化し, 覆工の一部を モデル化し，地盤とともに強制的に沈下させ，とも下がり現 象を表現することを行った。実際には，覆工の一部をモデル 化した模型の下部に位置するモデル地盤を強制的に沈下さ せ，地盤・覆工模型ともに沈下させることで，とも下がり現 象を表現する。

\section{2 実験装置}

覆工模型とモデル地盤を強制的に沈下させるため，ここで は 3 次元降下床模型実験装置 ${ }^{8)}$ ～10) を用いて実験を行った。 図-2 に, 本実験で用いた 3 次元降下床実験装置の外観と覆工 模型の設置状況を示す。装置は降下床部，土槽部，地表面計 測ユニットで構成されている。土槽の寸法は，幅 $1000 \mathrm{~mm}$, 奥行き $300 \mathrm{~mm}$ ，高さ $300 \mathrm{~mm}$ であり，底面にはとも下がり 現象を模擬するために下降させる降下床と荷重計測パネル $\mathrm{A} ， \mathrm{~B}$ が設置されている。降下床およびパネル A は $300 \mathrm{~mm}$ $\times 300 \mathrm{~mm}$ の正方形板であり，パネル $\mathrm{B}$ は $400 \mathrm{~mm} \times 300 \mathrm{~mm}$ の長方形板である。降下床の下部にはジャッキが接続されて おり, 鉛直下方に変位を与えることができる。ジャッキの鉛 直変位量は，接触式変位計により計測し，降下床及び荷重計 測パネルの下に設置された荷重計により, 各々に作用する鉛 直荷重を計測する。模型地山の地表面変位は, 図-2の上部に 示す地表面変位計測システムを用いて計測する。

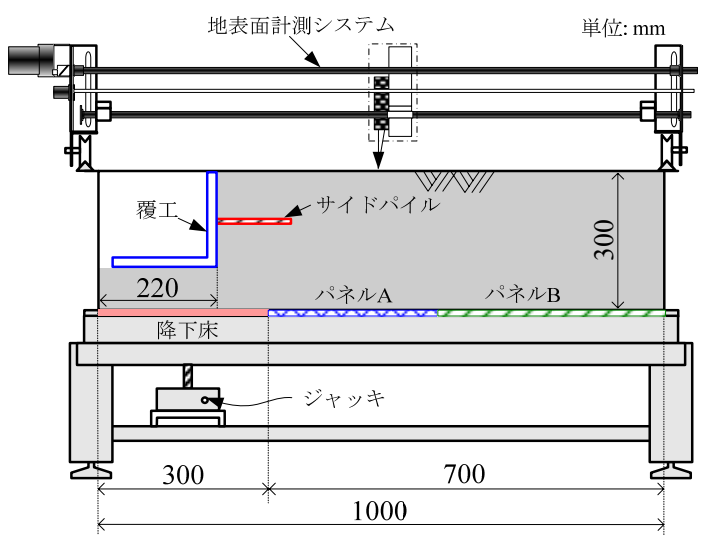

図-2３次元降下床実験装置

\section{3 トンネル覆エ及びサイドパイル模型}

トンネル覆工模型を図-3に示す。同模型は実際のトンネル
覆工上半掘削時の側壁・脚部をモデル化したものであり, $\mathrm{L}$ 字型の断面形状をしている。模型は無垢のアルミ製であり， 覆工の変形を考慮しない剛な模型としてモデル化した。また, 側壁部にはサイドパイル模型を設置するため, 直径 $5 \mathrm{~mm} の$ 穴が $25 \mathrm{~mm}$ 間隔で計 11 箇所空けられている。

サイドパイルは，直径 $5 \mathrm{~mm}$ の丸棒でモデル化した。表-1 に実施工と本模型実験でのサイドパイルの各パラメータを 示す。実施工でのサイドパイルの諸元は, 文献 1)を参照した。 模型実験では，卓越するモードに対して相似則を合わせるこ とが前提となる。本実験では, サイドパイルの効果は主にパ イルと周辺地盤の相対剛性およびパイルの曲げ剛性などに 大きく関連すると考えられる。しかしながら，両方を同時に 満足させることは不可能であるため, サイドパイル模型の材 料は, サイドパイルと周辺地盤の相対岡性に着目し, 地盤と の相対剛性が最も実施工に近くなるラミン材を使用した。こ こで, 模型実験での地盤のヤング率は, 模型実験での地表面 沈下量に対するフィッティング解析により得られたもので ある。さらに直径および設置間隔は，実施工でのサイドパイ ルの直径と設置閒隔の比率を考慮して設計した。

菊本ら ${ }^{9}$ は, 三次元降下床模型実験および数值解析手法を 用いて，トンネル掘削時の力学挙動について検討を行い，土 被り比 H/D（土被り/ 降下床幅）が 0.5 のケースにおいて, 降下床を $2 \mathrm{~mm}$ 下降させた場合, 地表面は図-4 に示す曲線の ように沈下寸ることを確認している。同図より，地表面は

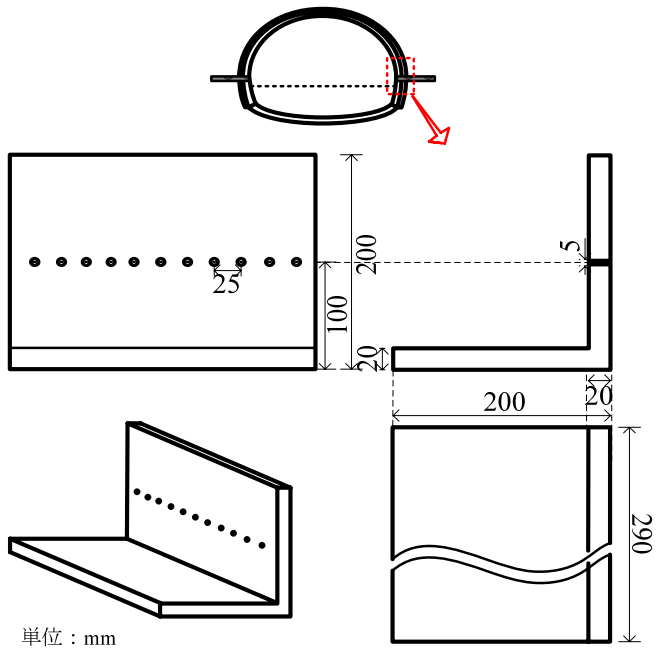

図-3 トンネル覆工模型

表-1＼cjkstart模型実験で用いるサイドパイルの材質および寸法

\begin{tabular}{c|c|c}
\hline 諸元 & 実施工 & 模型実験 \\
\hline \hline 材料 & 鉄 & ラミン材 \\
\hline ヤング率 $E_{p}\left[\mathrm{kN} / \mathrm{m}^{2}\right]$ & $2.0 \times 10^{8}$ & $14.2 \times 10^{6}$ \\
\hline $\begin{array}{c}\text { 地盤のヤング率 } E_{e} \\
{\left[\mathrm{kN} / \mathrm{m}^{2}\right]}\end{array}$ & $2.0 \times 10^{412)}$ & $2.13 \times 10^{3}$ \\
\hline 相対剛性 $E_{p} / E_{e}$ & $1.0 \times 10^{4}$ & $0.7 \times 10^{4}$ \\
\hline 設置間隔 $D[\mathrm{~mm}]$ & 1000 & 50 \\
\hline 直径 $d[\mathrm{~mm}]$ & 65 & 5 \\
\hline 直径/設置間隔 $\mathrm{d} / D$ & 0.065 & 0.1 \\
\hline \hline
\end{tabular}

実施工の值は，地盤のヤング率を除いて文献 1)を，地盤のヤング率は，文献 12)を参照 


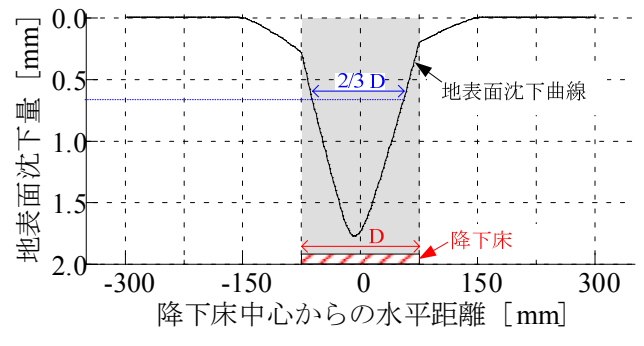

図-4＼cjkstart降下床の下降による生じる地表面沈下 ${ }^{9)}$

表-2 豊浦硅砂と模型地盤の諸元

\begin{tabular}{c|c}
\hline \hline 比重 $G s$ & 2.64 \\
\hline 単位体積重量 $\gamma\left[\mathrm{kN} / \mathrm{m}^{3}\right]$ & 15.5 \\
\hline 平均粒径 $D_{50}[\mathrm{~mm}]$ & 0.2 \\
\hline 内部摩擦角 $\phi\left[{ }^{\circ}\right]$ & 37 \\
\hline 粘着力 $C[\mathrm{kPa}]$ & 0 \\
\hline 間隙比 $e$ & 0.627 \\
\hline 最大間隙比 $e_{\max }$ & 0.982 \\
\hline 最小間隙比 $e_{\min }$ & 0.58 \\
\hline ポアソン比 $v$ & 0.33 \\
\hline 相対密度 $D_{r}[\%]$ & 88.3 \\
\hline \hline
\end{tabular}

表-3 実験ケース

\begin{tabular}{c|c|c|c}
\hline \hline 間隔 D [mm] & 25 & 50 & 75 \\
\hline \hline 0 & & Case-0 & \\
\hline \hline 100 & & Case-1 & \\
\hline 150 & & Case-2 & \\
\hline 200 & Case-6 & Case-3 & Case-7 \\
\hline 250 & & Case-4 & \\
\hline 300 & & Case-5 & \\
\hline \hline
\end{tabular}

注 : 長さ 0 はサイドパイル設置しない場合を示す。

降下床の中心から左右 $55 \mathrm{~mm}$ （約降下床幅の 2/3）位の領域 で大きい地表面沈下（降下床下降量の $1 / 3$ 以上）が生じるこ とが確認できる。トンネルの脚部と地表面でほぼ同じ沈下量 が生じる現象を表現するには，覆工模型をできるだけ明確な 沈下量が生じる領域内に設置する必要がある。そこで本実験 では，図-2に示すように覆工を降下床左端から $220 \mathrm{~mm}$ （降 下床幅の $2 / 3$ 位）の領域に設置した。本実験では，とも下が り現象で地表面とトンネル周辺が同程度沈下寸ることを考 慮し, 降下床の下降により直上地盤を沈下させ，地盤の沈下 に伴い覆工が沈下するようにした。覆工の沈下量が極力降下 床の下降量と同じようにするには, 覆工を降下床と同一の移 動をする 1 次領域 ${ }^{11}$ に設置する必要がある。したがって, 覆 工底面から降下床の間に設置する砂層の厚さは, 降下床幅の 1/3 である $100 \mathrm{~mm}$ とし，覆工が 1 次領域内に位置するよう にした。

\section{4 模型地山}

模型地盤の地山材料には，乾燥した豊浦硅砂を用いた。模 型地盤は，地表面から約 $600 \mathrm{~mm}$ の高さから豊浦硅砂を気中 落下させて作製した。これにより，均一な模型地盤を高い再 現性をもって作製することが可能である。豊浦硅砂とそれに より作製した模型地盤の諸元を表-2に示す。

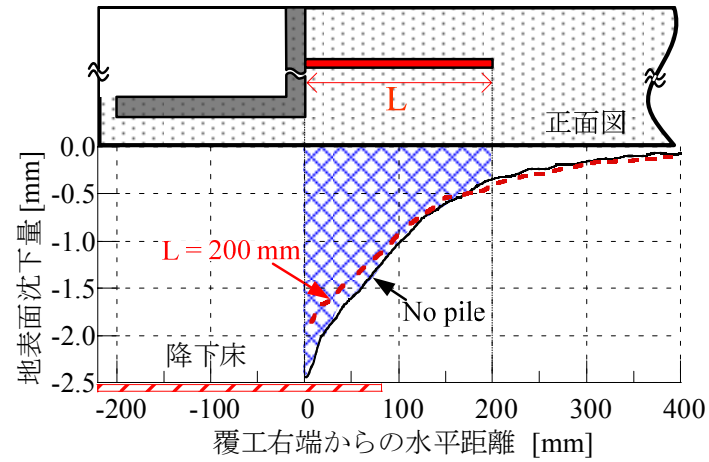

図-5＼cjkstart地表面沈下曲線

\section{5 実験ケース}

まず，とも下がり現象を再現するため覆工模型のみを設置 して実験を行った。ここで得られた地表面の沈下形状が，と も下がり現象の確認を行うだけでなく, サイドパイル工を挿 入した各ケースと比較検討を行うための基礎情報となる。つ づいて, 長さ $200 \mathrm{~mm}$ のサイドパイルを $50 \mathrm{~mm}$ おきに設置し たケースを実施し，サイドパイル無しのケースと比較する。 これにより, サイドパイル工の地表面沈下抑制メカニズムに ついて考察を行う。さらに, 長さと設置間隔をパラメータと した実験を行い, 各パラメータが地表面沈下抑制効果に及ぼ す影響について検討を行う。表-3に, 本研究で行った実験ケ 一スの一覧を示す。表-3 に示寸 Case-3 が，本研究での実験 の基本ケースとなる。

\section{3. 模型実験結果および考察}

\section{1 地表面沈下量}

トンネルの掘削による地表面沈下は, おおよそ正規分布曲 線の形状を示し，トンネルの直上地盤で最も大きい沈下が生 じるとされている ${ }^{1)}$ 。図-5に, サイドパイルを設置しない場 合と長さ $200 \mathrm{~mm}$ のサイドパイルを $50 \mathrm{~mm}$ 間隔で設置した場 合，それぞれの降下床を $3 \mathrm{~mm}$ 下降させた時の地表面沈下形 状を示す。横軸には, 覆工模型側壁端部からの水平距離を示 した。図より, サイドパイルを設置しない場合, 地表面沈下 量は降下床に近いほど大きく, 覆工上端面と地表面の境界付 近で最大地表面沈下量が発生する。これは，実際の地表面沈 下量と同じ傾向を示し, 本実験では地表面沈下を適切に表現 できたと考えられる。最大の沈下量は，2.5 mm である。模 型底部より $100 \mathrm{~mm}$ 下部の降下床を $3.0 \mathrm{~mm}$ 下降させており, 模型周辺は地表面と同程度沈下しているものと考えられる。 したがって, 本研究で検討する図-1に示すとも下がり現象は, 再現できているものと考える。さらに, サイドパイルを設置 した場合, 覆工付近では地表面沈下量が小さくなる。これは, サイドパイルの設置により, 地表面の沈下を抑制する効果を 表しているものと考える。

定量的に検討を行うため, 最大地表面沈下量と区間平均地 表面沈下量を用いて検討を行う。図-5より, 最大地表面沈下 量は，覆工と地盤の境界で生じる。一方，区間平均地表面沈 下量は, 図-5に示すように, ある計測位置までの沈下曲線の 面積（図中の網掛け部分）を計測長さ（図中ではL) で割っ 


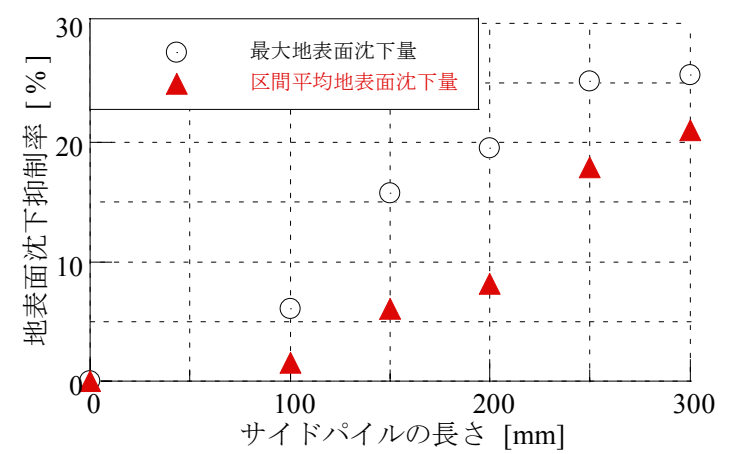

図-6 長さが地表面沈下抑制率に及ぼす影響

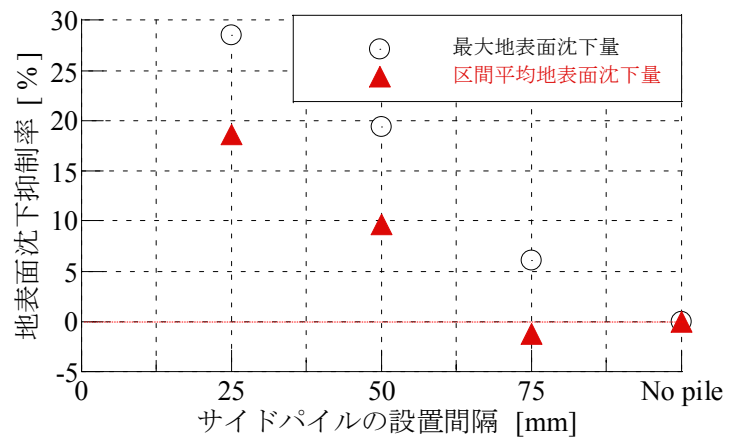

図-7 設置間隔が地表面沈下抑制率に及ぼす影響

たものであり，地表面の全体的な沈下程度を表現できる。本 研究では, 長さと設置間隔の変化による地表面沈下量の差異 が顕著である覆工右端から $200 \mathrm{~mm}$ の領域での区間平均地表 面沈下量を用いて議論を行う。

これらの指標を用いて, 表-3に示す各ケースの比較を行い, サイドパイルの長さと設置間隔が，地表面沈下抑制効果にど のような影響を及ぼすかについて検討を行う。

図-6 に最大地表面沈下量と区間平均地表面沈下量による, サイドパイルの長さと地表面沈下抑制率の関係を示す。ここ で，地表面沈下抑制率はサイドパイルを設置しないケースに 対する各ケースでの最大地表面沈下量および区間平均地表 面沈下量の減少率を示す。図に示す最大地表面沈下量は，サ イドパイルが長くなるほど沈下抑制率は大きくなり，250 $\mathrm{mm}$ 以上になるとその効果はほぼ増加しなくなる。一方，区 間平均地表面沈下量では，サイドパイルの長さが $150 \mathrm{~mm}$ か ら抑制効果率が顕著に現れ，長くなるほどその効果が大きく なる。このことから, サイドパイルが $100 \mathrm{~mm}$ より長くなる と覆工付近の地表面沈下量が抑制され，さらに $150 \mathrm{~mm}$ より 長くなると，全領域にわたって地表面沈下を抑制することが 可能であることが確認できる。

つぎに, 図-7に最大地表面沈下量と区間平均地表面沈下量 による, サイドパイルの設置間隔と地表面沈下抑制率の関係 を示す。図から, 設置間隔が広くなるほど最大地表面沈下量 と区間平均地表面沈下量いずれの值でも沈下抑制効効果が 小さくなることが確認できる。設置間隔が $75 \mathrm{~mm}$ のケース では，最大地表面沈下量および区間平均地表面沈下量のいず れもサイドパイルを用いない場合と同じとなり, サイドパイ ルの効果がほぼ発揮されていない結果となった。

図-6, 7 の結果から，いずれも区間平均地表面沈下量の抑 制率が最大地表面沈下量の抑制率より小さい值を示す。これ

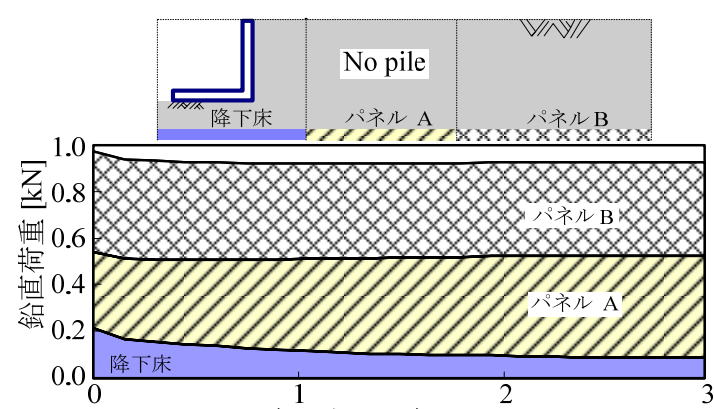

降下床の下降量 $[\mathrm{mm}]$

図-8 降下床および周辺地山に作用する鉛直荷重

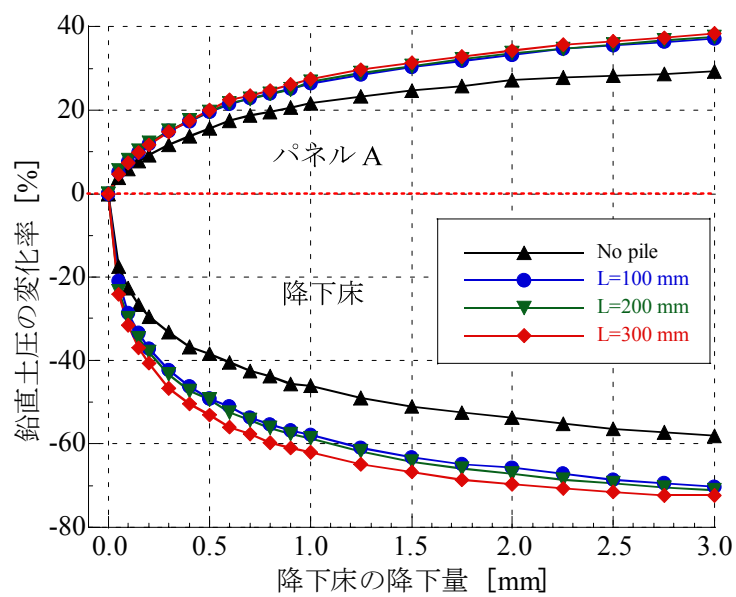

図-9 長さが鉛直荷重に及ぼす影響

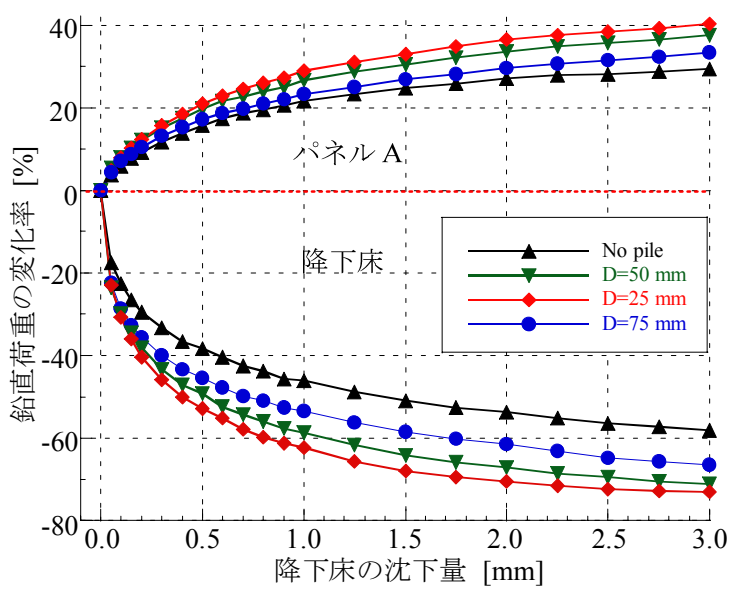

図-10 設置間隔が鉛直荷重に及ぼす影響

は, 図-5に示すように, サイドパイルの設置により, 覆工模 型付近の地表面沈下量が抑制されたことに対して, 覆工模型 から離れた領域では，サイドパイルを設置しないケースと同 等の地表面沈下が発生しているからである。サイドパイルに よる沈下抑制効果は, 覆工模型付近で顕著に表れるため, 覆 工近傍に発生する最大地表面沈下量に顕著に抑制効果が現 れる傾向となった。

\section{2 鉛直荷重}

図-8 にサイドパイルを挿入しないケースの降下床および 周辺地山に作用する鉛直荷重の推移を示寸。図より，降下床 の下降に伴い，降下床に作用する荷重は減少し，その減少分 を負担する形でパネル A に作用する荷重が増加する。一方, 降下床から遠く離れたパネル B では作用荷重がほとんど変 


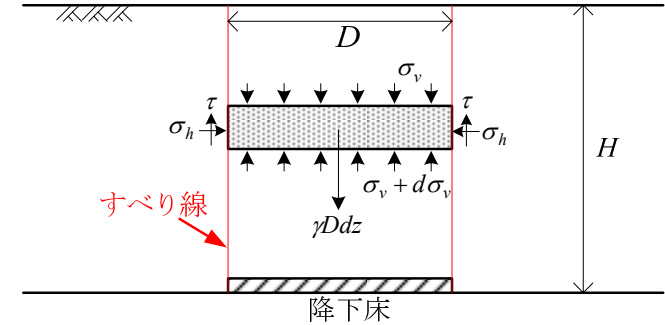

図-11 Terzaghi の式による降下床土圧の算定

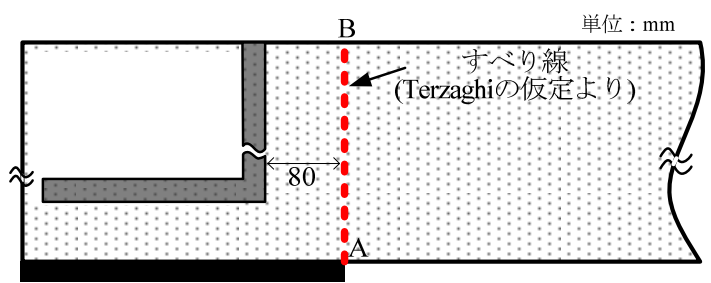

図-12 Terzaghi の仮定によるすべり線

化しない。なお，土槽底面全体に作用する荷重の合計は，ほ ぼ不変である。ここでは，地山底面における鉛直荷重につい て各実験ケースの比較を行う場合, 降下床およびパネル A に 作用する荷重の推移に着目し, 作用寸る荷重の変化率でサイ ドパイルの荷重分散効果を議論する。

図-9 は, サイドパイル長さごとの降下床およびパネル A に作用する鉛直荷重変化率の推移を示す。図から, サイドパ イルの設置により，降下床に作用する鉛直荷重が大幅に減少， パネル A に作用する鉛直荷重は, 減少分を負担する形で大幅 に増加する現象が見られる。さらに, 降下床とパネル A に作 用する鉛直荷重いずれも, サイドパイルが長くなるほどその 変化率が大きくなる傾向を示すが, その差異は顕著ではない。

図-10 は，サイドパイルの設置間隔を変化させた場合，降 下床およびパネル A に作用する鉛直荷重変化率の推移を示 す。図から, 設置間隔が狭くなるほど, 降下床およびパネル A に作用する鉛直荷重の変化率が大きくなることが確認で きる。

\section{3 考察}

降下床実験における Terzaghi の緩み土圧式 ${ }^{13)}$ は, 図-11 に 示すように降下床の下降とともに, 降下床端部から鉛直上方 にせん断面が形成されると仮定している。この考えに従えば, 本実験で降下床の下降により，図-12 に示寸線 $\mathrm{AB}$ のような すべり線が形成されていると想定できる。サイドパイルは, このすべり線を横切ることでせん断補強効果を発揮し, 地盤 の沈下を防ぐことができると考えられる。図-6に示す実験結 果では, サイドパイルの長さが $100 \mathrm{~mm}$ より長くなると最大 地表面沈下量が抑制されることを示している。サイドパイル の長さは, 覆工から想定すべり線までの距離より長く, すべ り線を横切るため, せん断補強効果が発揮されたと考えられ る。

一方, 図-9, 10 の結果から, サイドパイルの設置により降 下床に作用する鉛直荷重が，大幅に軽減され，さらにそれを 受け取る形でパネル A に作用する鉛直土圧が大幅に増加す ることが確認された。このことから, サイドパイルの設置に

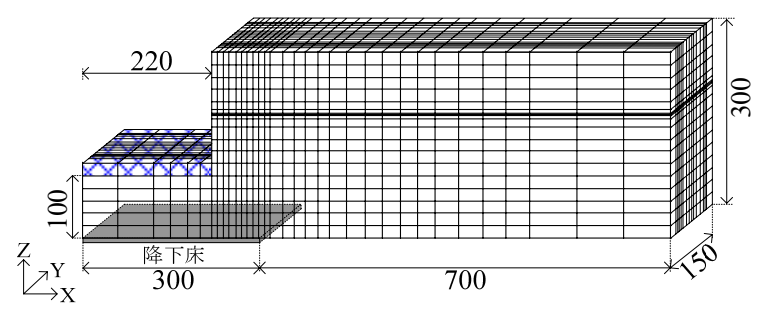

図-13 模型実験に対する解析メッシュ

より，覆工模型下部地盤に作用する荷重が，覆工模型から離 れた健全な地盤に分担させ, 覆工模型の沈下を抑制できてい ると考える。すなわち, サイドパイルは, 先端部分が健全な 地盤に位置することで, 土圧の再分配を健全な地盤にうなが し, 荷重分散効果を発揮できる。ここに示した実験結果と先 ほどのすべり線の考えを統合すれば，サイドパイルが 100 $\mathrm{mm}$ の場合, 先端の $20 \mathrm{~mm}$ 長の部分が, パネル $\mathrm{A}$ 上部の健 全な地盤に位置するため, 荷重分散効果が得られたと考えら れる。

\section{4. 数值解析による検討}

ここでは, 模型実験に対する数值解析を実施する。目的は, 模型実験に対する数值解析の適用性を検証し, さらに実験で は計測困難である地盤中の土圧の変化や変形, サイドパイル の挙動を把握し, サイドパイルの効果に更なる考察を加える ためである。本研究では, 3 次元弾塑性有限要素法を用いて 数值解析を実施した。

\section{1 数值解析の概要 \\ 4.1.1 解析領域とメッシュ}

図-13 に模型実験に対する解析メッシュを示す。本解析で は, 模型実験を対象とし, 奥行き方向は, 地盤および実験条 件に関して対称性を見出せることから，解析領域を模型地盤 の半分にして実施した。覆工模型をモデル化する際, 覆工模 型が剛であることおよび壁面が平滑であることを考慮して, 覆工模型の底面だけを要素化し, 覆工模型壁面は X方向の変 位を制御することとした。これにより, 模型実験で覆工模型 が直下方向のみ移動できる現象をモデル化した。解析対象領 域の側面および降下床部を除く底面では, 面に垂直な方向の 変位の夕拘束する。すなわち, $\mathrm{YZ}$ 面と平行な境界は, $\mathrm{X}$ 方 向の変位を拘束し, XZ 面に平行な境界は, $\mathrm{Y}$ 方向の変位を 拘束する。さらに, 降下床の下降は, 降下床直上の節点に鉛 直下方への強制変位を与えることで模擬する。

\subsection{2 地山のモデル化}

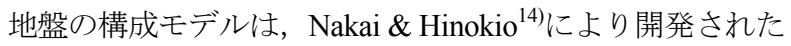
subloading tij model を用いた。解析に用いるパラメータは表-2 に示したポアソン比, 密度, 間隙比の他, 破壊時の主応力比 $M_{f}$, 密度項 $a$, 応力 - ダイレイタンシーパラメータ $\beta$, 圧密 指数 $\lambda$, 膨潤指数 $\kappa$ があ。主応力比 $M_{f}$ は Iizuka \& Ohta ${ }^{15)}$ の 方法により決定し, 他パラメータは同じ豊浦硅砂を利用した 参考文献 14)の值を準用した。各值は $M_{f}=1.506, a=500, \beta=$ $2.0, \lambda=0.07, \kappa=0.0045$ である。 


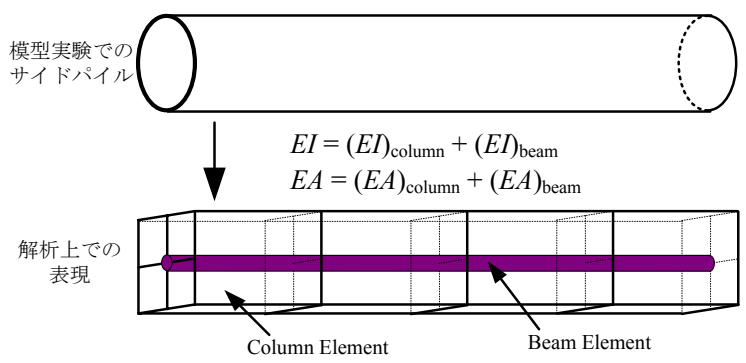

(a) サイドパイルモデルの概略

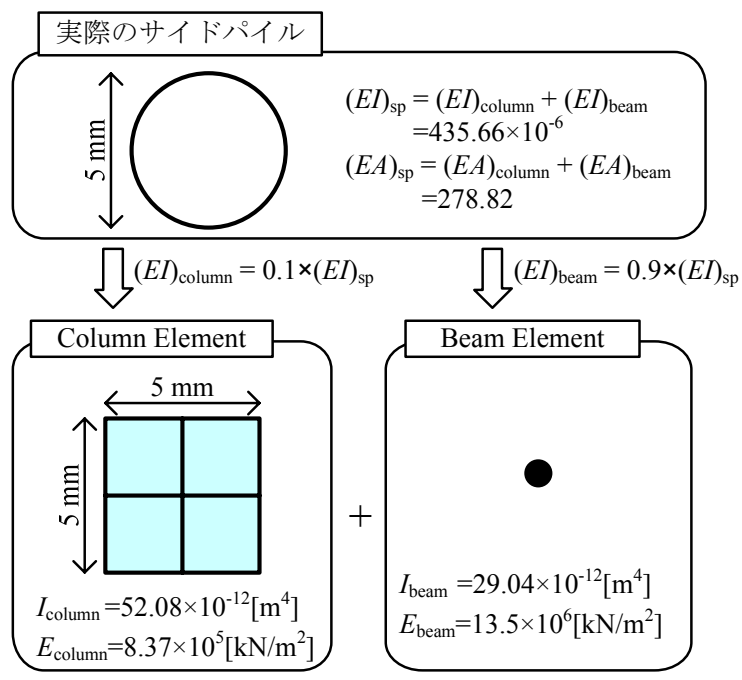

(b) サイドパイルモデルのパラメータ決定フロー

図-14 サイドパイルモデル化概略とパラメータの決定

\subsection{3 サイドパイルのモデル化}

本解析では，サイドパイルの挙動を簡便に計算し，かつサ イドパイルの体積を適切に表現するために, Zhang ら ${ }^{16)}$ の研 究を参考とし，ビーム要素の周囲にサイドパイルの曲げ剛性 の1割を分配した弾性コラム要素を配置したハイブリッド要 素でサイドパイルをモデル化した。図-14 にモデルの概略図 と各パラメータの決定方法, およびこの方法により決定され た各值を示す。ビーム要素とコラム要素の密度, およびポア ソン比は両方模型実験で用いたラミン材の物性值と同じ值 $\left(\rho=1.55 \mathrm{~kg} / \mathrm{m}^{3}, v=0.4\right)$ を準用した。ただし, 本モデルで はサイドパイルの断面を実際直径と同じ幅を持つ正方形断 面でモデル化したため, その断面積が大きくなり, パイルの 効果を過大評価している可能性がある。

\section{2 模型実験値との比較}

図-15 は，長さ $200 \mathrm{~mm}$ のサイドパイルを $50 \mathrm{~mm}$ 間隔で設 置したケースの，降下床下降量と最大地表面沈下量の減少率 の関係を示す。図より，実験值・解析值とともに降下床の下 降量が大きくなるほど地表面沈下量の抑制率が大きくなる。 さらに，解析值が実験值より大きい值を示寸傾向がある。そ の原因としてサイドパイルのモデル化とサイドパイルと地 盤の相互作用の 2 点が考えられる。

模型実験でのサイドパイルは，直径 $5 \mathrm{~mm}$ の丸棒を使用し ているのに対し, 数值解析では, 幅 $5 \mathrm{~mm}$ の長方形断面を持 つ直方体でモデル化されている。これにより, 解析でのサイ ドパイルの表面積は, 実験より大きくなり, サイドパイルの

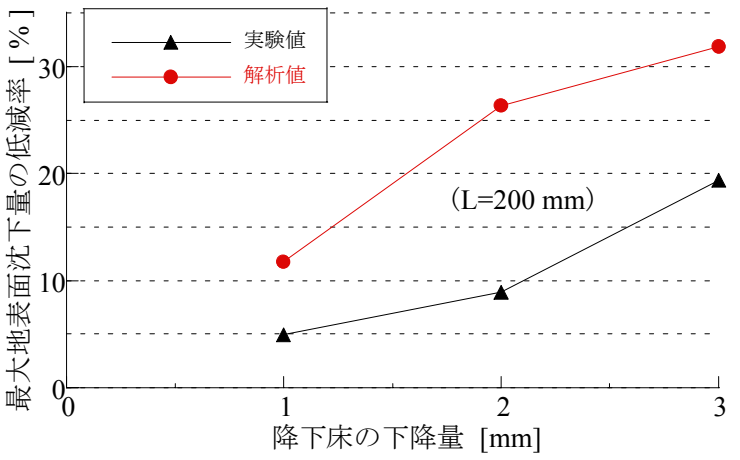

図-15 降下床下降量の変化による沈下抑制率の差異

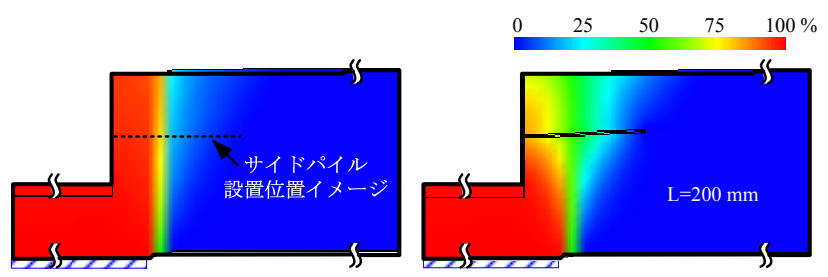

(a) サイドパイル無し

(b) サイドパイル有り

図-16 サイドパイル設置による地山鉛直変位の変化

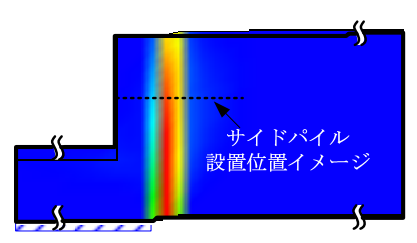

(a) サイドパイル無し

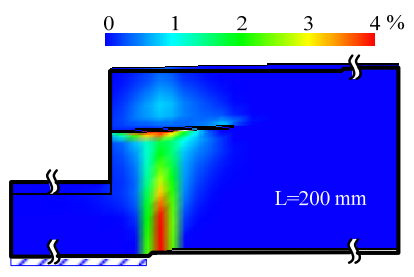

(b) サイドパイル有り

図-17 サイドパイル設置によるせん断ひずみ分布の変化 効果が過大に現れたと考えられる。

また, 模型実験でのサイドパイルは, 表面が滑らかである ため, 周辺地盤との間に相対変位が発生すると考えられる。 しかしながら数值解析では, サイドパイルに隣接した地盤要 素はサイドパイルのコラム要素と同じ節点を共用している ため, 地盤の変形はサイドパイルの変形に左右される。した がって, 数值解析で剛なサイドパイルの変形に地盤が追従す ることになり, サイドパイルの効果が過大に現れたものと考 える。

以下では, 降下床を $2 \mathrm{~mm}$ まで下降させた場合の数值解析 結果を用い, 地盤およびサイドパイルの挙動について検討し, サイドパイルの地表面沈下抑制効果について考察を加える。

\section{5. 解析結果および考察}

\section{1 地盤の力学挙動}

\subsection{1 サイドパイル設置前後の比較}

図-16 は, 降下床を $2 \mathrm{~mm}$ 下降させた時点での, 地盤内部 の鉛直変位の降下床下降量に対する比率分布を示す。図 -16 (a)の点線は, サイドパイルの設置位置をイメージしたも のである。図-16(a)より, サイドパイルを設置しない場合, 降下床直上部地盤は, 降下床下降量と同等の変位が生じ, そ の変形は地表面に同等の量として現れる。これに対し図 -16 (a)に示すようにサイドパイルを設置することにより, 降 


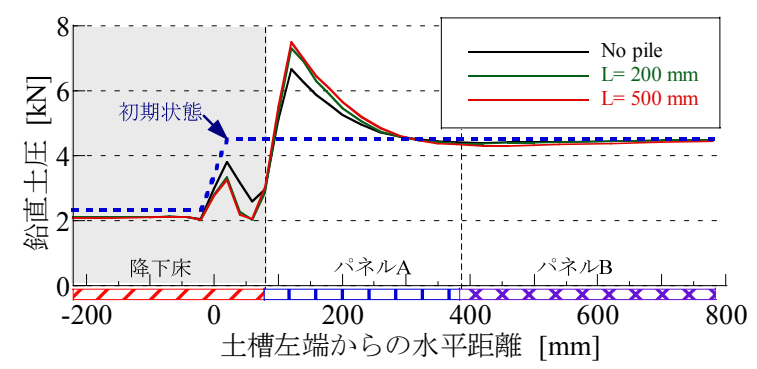

図-18 周辺地盤の鉛直土圧分布

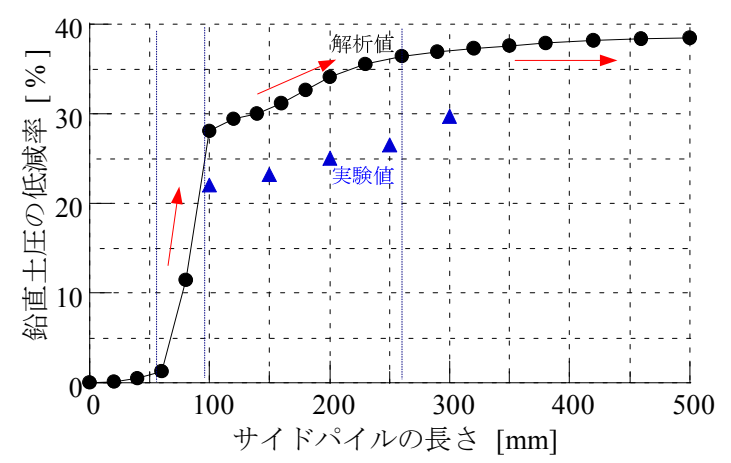

図-19 長さが鉛直土圧の減少率に及ぼす影響

(降下床上部)

下床直上の変位は，降下床下降量と同等であるが，サイドパ イル上部地盤の鉛直変位が小さくなっていることが確認で きる。これにより，地表面沈下量が抑制され，特に挿入され たサイドパイル上部の覆工周辺地盤での沈下抑制効果が確 認できる。

図-17 は, 降下床 $2 \mathrm{~mm}$ 下降時の, 地山に生じるせん断ひ ずみ分布を示す。サイドパイルを設置しない場合，降下床端 部から上部に向かい，直線的にせん断ひずみが発生している ことが確認できる。一方, サイドパイルを設置した場合, サ イドパイルの周辺および上部に発生するせん断ひずみが小 さくなることが分かる。これから，地盤に発生するせん断ひ ずみはサイドパイルにより遮断され，地表面まで発達するせ ん断ひずみが小さくなり, 地表面沈下が抑制されると考えら れる。

図-18 は，降下床下降前後に地山底面の中心線に生じる鉛 直土圧の分布を示す。図中の点線部分は, 降下床下降前の初 期鉛直土圧分布である。図より，サイドパイルを設置しない 場合と設置する場合いずれも，降下床の下降により鉛直土圧 は降下床上部で減少, パネル $\mathrm{A}$ 上部で増加, パネル $\mathrm{B}$ 上部 でほぼ不変となる傾向を示す。これは実験結果と同じ傾向を 示している。一方, 長さ $200 \mathrm{~mm}$ あるいは $500 \mathrm{~mm}$ のサイド パイルを設置した場合, 降下床の上部地盤に作用する鉛直土 圧は, サイドパイルがない場合の初期土圧からの減少量より 多くなり, パネル A 上部地盤に作用する鉛直土圧の増加量も 多くなる。これから，降下床に作用する鉛直荷重はサイドパ イルの設置により, パネル $\mathrm{A}$ 上の安定した地盤に分担されて いると考えられる。

\subsection{2 長さが地盤の力学挙動に及ぼす影響}

図-19に, 解析で得られた, サイドパイルの長さと降下床 に作用する鉛直土圧の低減率の関係を実験值と合わせて示

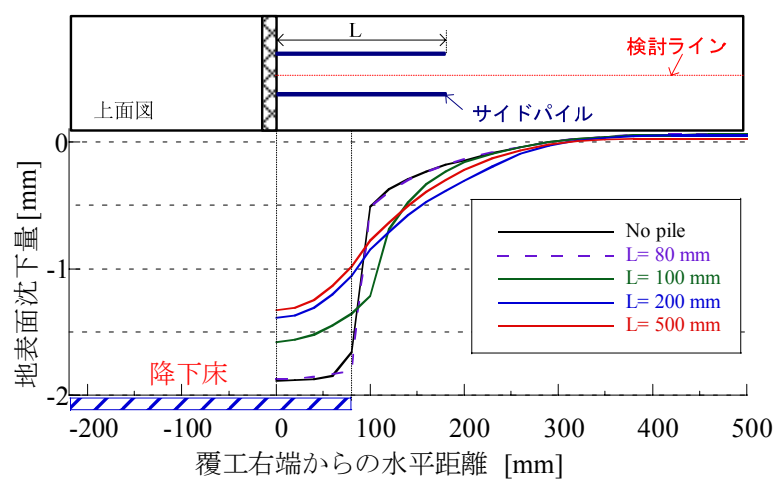

(a) 地表面沈下曲線

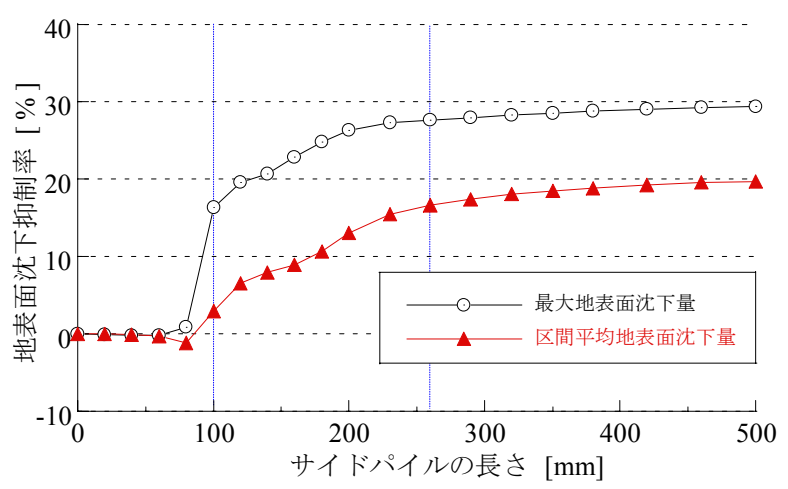

(b) 地表面沈下抑制率

図-20 長さが地表面沈下抑制効果に及ぼす影響

す。ここで示寸鉛直土圧の低減率は, サイドパイルを設置し た場合，設置しないケースに比べて，鉛直土圧の初期状態か らの減少率がどれぐらい増加したかを示し, 各ケースでの応 力分布曲線と初期応力分布曲線間の面積の百分率で表す。解 析值から, 長さが $60 \mathrm{~mm}$ より短い場合, 降下床に作用する 鈆直土圧はあまり変化しない。一方, $60 \mathrm{~mm} \sim 100 \mathrm{~mm}$ の区 間では, 鉛直土圧の低減率が急激に増加寸ることが確認でき る。確かに，実験においても $100 \mathrm{~mm}$ では明確な土圧低減効 果が確認できる。さらに, $100 \mathrm{~mm}$ を超えると低減率は漸増 し， $260 \mathrm{~mm}$ を過ぎると一定值となる。覆工側壁から降下床 右端まで,すなわち覆工側壁から安定な地盤までの距離は 80 $\mathrm{mm}$ である。サイドパイルの先端が，パネル $\mathrm{A}$ 上部の安定な 地盤に達すると降下床に作用する鉛直土圧が減少していう ることになる。さらに同図から, 解析値は実験值より大きい 值を示寸ものの, 実験值とほぼ同じ傾向を示寸ことが確認で きる。解析值が実験值より大きい值を示すのは, 4.2 節での 説明したのと同じく, サイドパイルのモデル化とサイドパイ ルと地盤の相互作用の 2 点が考えられる。

図-20 (a) に，長さ $80 ， 100 ， 200 ， 500 \mathrm{~mm}$ のサイドパイル を設置した時の地表面沈下曲線を, 図-20(b) に, 最大地表面 沈下量と区間平均地表面沈下量によるサイドパイルの長さ 沈下抑制率の関係を示す。図から, $80 \mathrm{~mm}$ のサイドパイルを 設置した場合, 地表面沈下は抑制されないが，100 mmにな ると覆工付近の地表面沈下量が小さくなることが確認でき る。さらに, $200 \mathrm{~mm}$ のサイドパイルを設置した場合, $100 \mathrm{~mm}$ のケースに比べて, 地表面沈下量が大幅に減少しているのに 対し, $500 \mathrm{~mm}$ と $200 \mathrm{~mm}$ のケースでの地表面沈下量の差は 顕著でない。図-20(b)から, 長さが $100 \mathrm{~mm}$ になると最大地 


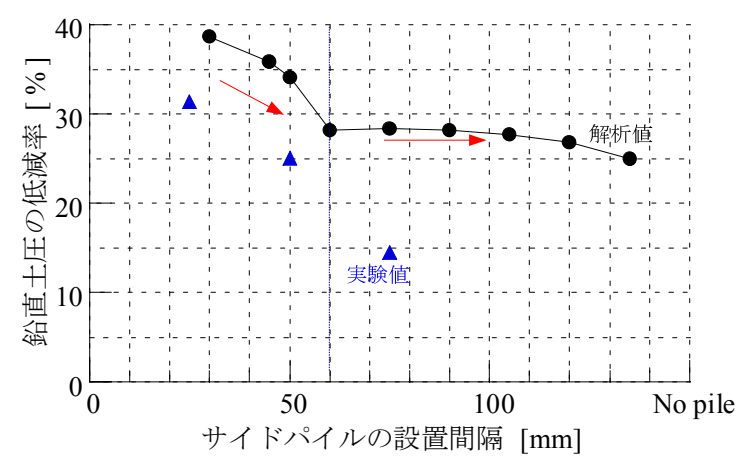

図-21 設置間隔が鉛直土圧の減少率に及ぼす影響 (降下床上部)

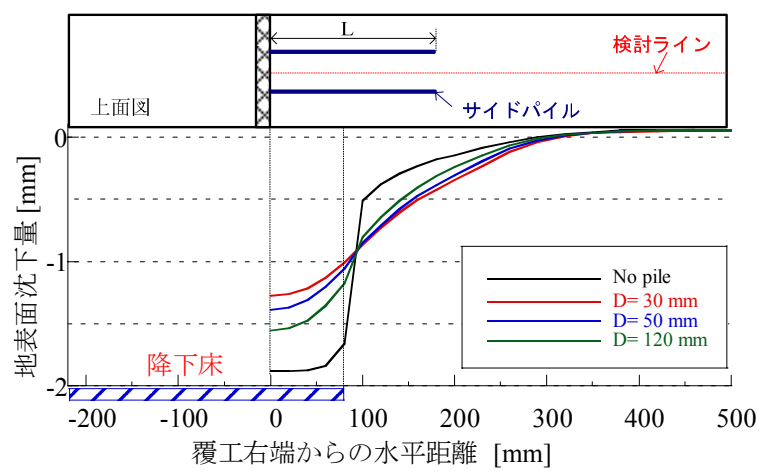

(a) 地表面沈下曲線

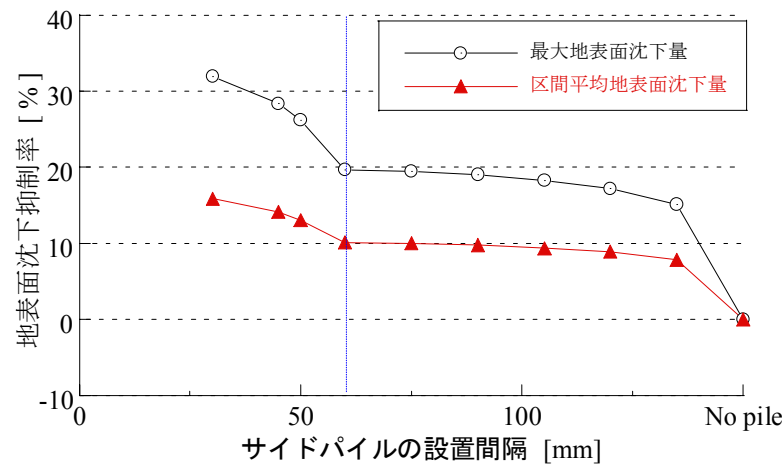

(b) 地表面沈下抑制率

図-22 設置間隔が地表面沈下抑制効果に及ぼす影響

表面沈下と区間平均地表面沈下とも抑制され，長さの増加と ともにその抑制率が大きくなることが確認できる。しかしな がら, $260 \mathrm{~mm}$ 以上になるとその効果が一定となる。これは， 図-19 に示した長さと鉛直土圧の関係と同じ傾向を示す。

\section{1 .3 設置間隔が地盤の力学挙動に及ぼす影響}

図-21に，設置間隔と降下床上部地盤に作用する鉛直土圧 の低減率の関係を示す。図には, 解析結果と実験結果の双方 を示す。眓から, サイドパイルは設置間隔が狭くなるほど降 下床に作用する鉛直土圧の変化率が大きくなる傾向を示す が，設置間隔が $60 \mathrm{~mm}$ 以上になると鉛直土圧の低減率が急 激に減少し，設置間隔の増加による影響が顕著でないことが 確認できる。これは，パイルの設置間隔が $60 \mathrm{~mm}$ より狭い 場合，隣接する二つのパイルの影響領域が重なり，パイルの 効果が増すことに対して, $60 \mathrm{~mm}$ より広くなるとその効果が なくなるためであると考えられる。さらに，設置間隔による 鉛直土圧の差異に対する解析結果も，実験值より大きい值を 示すが，実験值とほぼ同じ傾向が得られた。

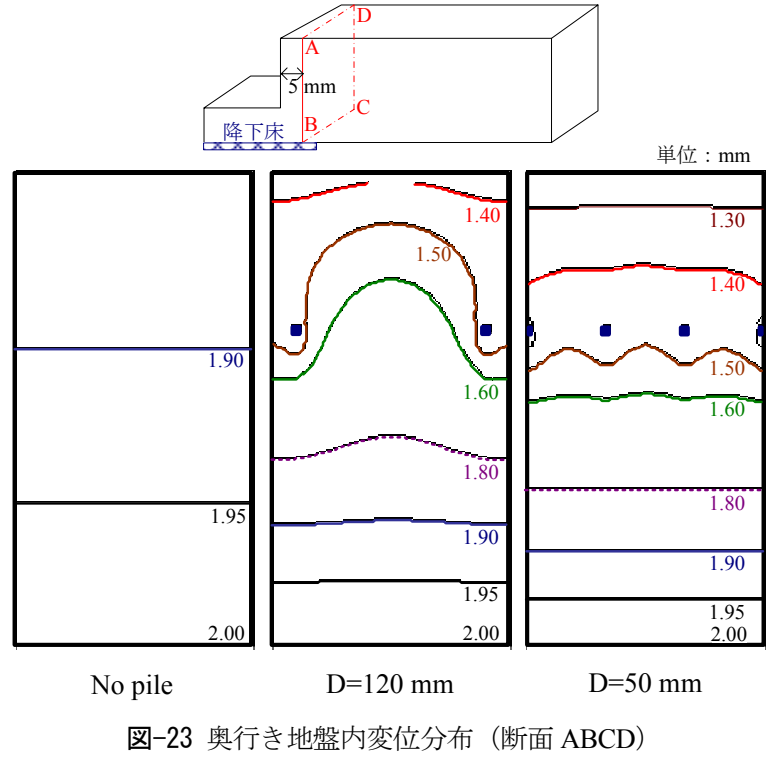

図-22 を用いて，サイドパイルの設置間隔と地表面沈下抑 制効果について検討を行う。図-22(a)に, 設置間隔が 30, 50, $120 \mathrm{~mm}$ の時の地表面沈下曲線を示す。図から, サイドパイ ルを密に設置するほじ覆工付近に生じる地表面沈下量が小 さくなる傾向が見られる。数值的にその傾向を把握するため, 図-22 (b)に, サイドパイルの設置間隔と地表面沈下抑制率の 関係を示す。図から, 最大地表面沈下量と区間平均地表面沈 下量いずれも, 設置間隔が狭くなるほどその抑制率が高くな る現象が見られる。設置間隔が $60 \mathrm{~mm}$ 以上になるとその効 果が激減し, 設置間隔による差異が見られなくなる。これは, 設置間隔が降下床上部地盤の鉛直土圧の低減率に及ぼす影 響と同じ傾向を示す。以上から本実験条件では，設置間隔が $60 \mathrm{~mm}$ 以上になると, サイドパイルによる鉛直荷重および地 表面沈下に効果が十分発揮されないことになる。

図-23 にサイドパイルを設置しないケースと， $200 \mathrm{~mm}$ の サイドパイルを $50,120 \mathrm{~mm}$ 間隔で設置したケースで, 降下 床上部領域の断面 $\mathrm{ABCD}$ (模型側壁から水平距離で $5 \mathrm{~mm}$ 離 れた箇所）に発生する鉛直変位の等変位線を示す。図から, サイドパイルのないケースでは降下床上部地盤の鉛直変位 は, いずれも降下床底面に発生する $2 \mathrm{~mm}$ の変位に追随する 形で，底面から離れるほど段々小さくなる現象が見られる。 鉛直変位 $1.90 \mathrm{~mm}$ の等変位線に着目寸ると, サイドパイルの 設置により等変位線の位置が低くなり, 設置間隔が狭くなる とさらに低くなる現象が見られる。これから, サイドパイル の設置により, 降下床の下降に追随して発生する鉛直変位が 抑制され, 設置間隔が狭くなるほどその効果が大きくなるこ とが確認できる。さらに, 設置間隔 $50 \mathrm{~mm}$ のケースでは, 地表面付近の同変位線 $(1.30 \mathrm{~mm})$ が直線であることに対し て，設置間隔 $120 \mathrm{~mm}$ のケースでは曲線 $(1.40 \mathrm{~mm})$ を示す ことが分かる。このことから, 設置間隔が $50 \mathrm{~mm}$ のケース では, サイドパイルの設置により一体的に地盤を支え地表面 の沈下を抑制しているが, 設置間隔が $120 \mathrm{~mm}$ のケースでは, その影響が局所的であり, 地表面に不等沈下が生じる結果と なっている。 


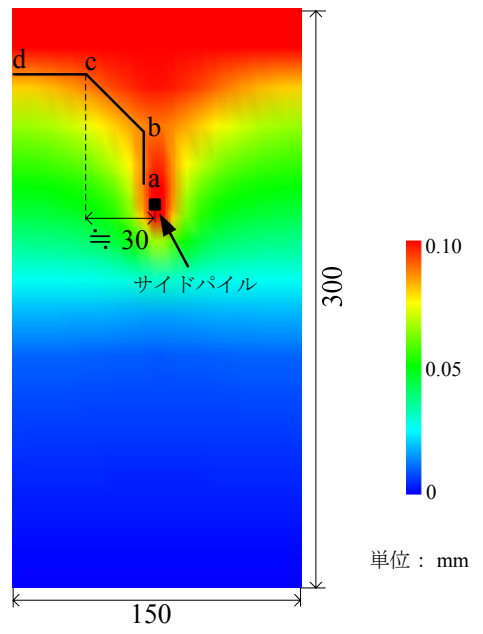

図-24 サイドパイルの影響範囲

(鈆直変位の変化量)

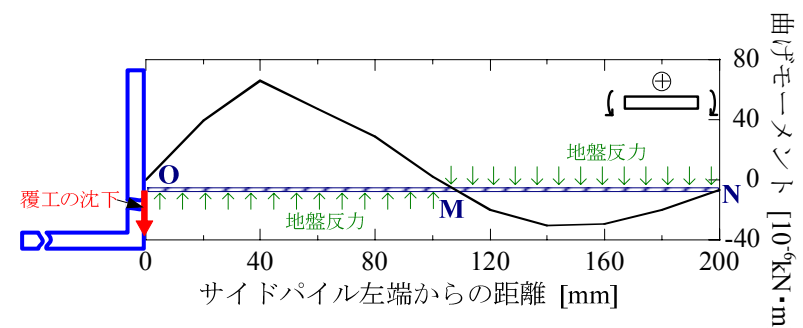

図-25 サイドパイルの力学挙動（曲げモーメント）

サイドパイルの設置間隔を決定する際は，1 本のサイドパ イルの影響範囲がどの程度であるかを評価する必要がある。 図-24 にサイドパイルを設置しないケースと 1 本のみ設置し たケースでの地盤内部に生じる鉛直変位の差, 寸なわち 1 本 のサイドパイルの設置による鉛直変位の減少量を示す。対象 エリアは, 図-23 に示す $\mathrm{ABCD}$ 断面である。図から, サイド パイルの設置により, サイドパイルの直上領域と地表面での 地盤の変位が大きく抑制される。眓中の折線 abcd は, サイ ドパイルによる鉛直変位の変化量が大きい領域をプロット したものである。図から, サイドパイルの影響範囲はその設 置位置から, 点 $\mathrm{C}$ までの領域であると考えられ, その横幅は 約 $30 \mathrm{~mm}$ である。サイドパイルの設置間隔を選定する際は, 隣接するパイルの影響領域が交差するのが望ましいと考え られる。本解析の条件では，一本のパイルの影響領域は 60 $\mathrm{mm}$ である。しかしながら，本解析ではパイルの断面積が実 際より若干大きいこと, およびパイルと地盤間の摩擦を考慮 できていないことから, パイルの効果が過大評価されている。 したがって，実際の一本のパイルの影響領域は $60 \mathrm{~mm} よ り$ 若干小さいと考えられる。

\section{2 サイドパイルのカ学挙動}

\section{2 .1 曲げモーメント}

図-25に長さ $200 \mathrm{~mm}$ のサイドパイルを $50 \mathrm{~mm}$ 間隔で設置 する場合, パイル全長に発生する曲げモーメント分布を示す。 本研究では, 上側引張りで下側圧縮となる 1 対のモーメント を正として表示する。同図に表示した矢印は, 曲げモーメン ト分布から推測できるサイドパイルに作用する力の状態で ある。サイドパイルと覆工の接続部分 $\mathrm{O}$ では, 覆工の下降量

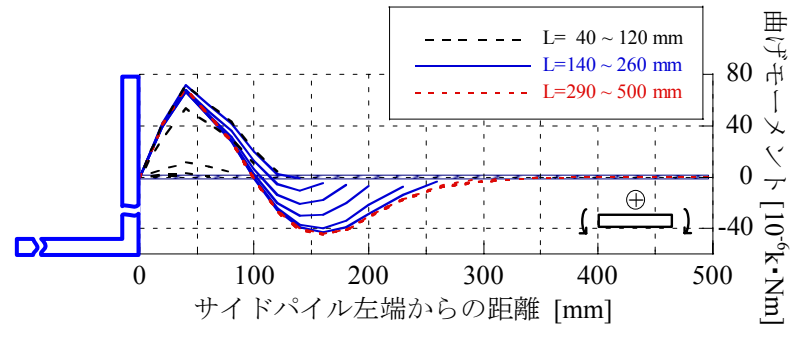

図-26 長さが曲げモーメント分布に及ぼす影響

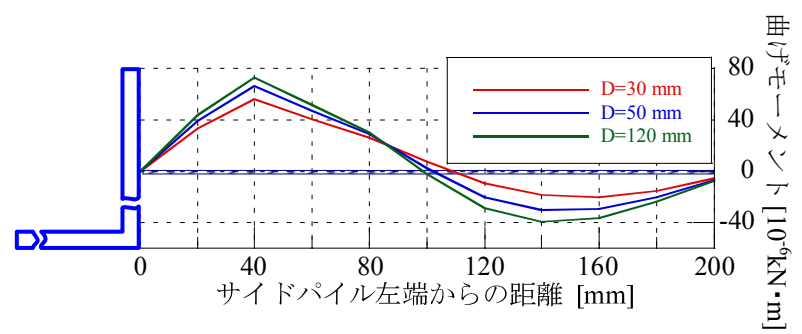

図-27 設置間隔が曲げモーメント分布に及ぼす影響

と同じ鉛直変位が生じる。OM 区間, すなわち覆工から 100 $\mathrm{mm}$ の領域では, 正の曲げモーメントが発生し, 図に示すよ うに上方向に地盤反力を受けると考えられる。これに対して， MN 区間では，負の曲げモーメントが発生し，パイルが上部 地盤に押えられる形で, 下方向に地盤反力を受けると考えら れる。さらに, 点 $\mathrm{M}$ では曲げモーメントが零となり, 降下 床の下降により生じる地盤のすべり線がこの位置を通ると 推測できる。

\subsection{2 長さがサイドパイルのカ学挙動に及ぼす影響}

図-26に，異なる長さのサイドパイルに生じる曲げモーメ ント分布を示す。横軸は, サイドパイル左端からの距離を示 している。図から, サイドパイルが $120 \mathrm{~mm}$ より短い場合, サイドパイル全長に正の曲げモーメントのみが発生し, 長く なるほど正の曲げモーメントの值が大きくなる。140 mm よ り長くなると端部に負の曲げモーメントが発生し, 長くなる ほどその最大值が大きくなるが, 正の曲げモーメントの最大 值は変化しない。さらに，260 mmより長くなるとパイル全 長に生じる曲げモーメントの形状がほぼ変化しない。これは, サイドパイルの長さが $260 \mathrm{~mm}$ より長くなると, 最大地表面 沈下量の低減率が一定になることと関連すると考えられる。 さらに, サイドパイルの長さに係わらず覆工から約 $100 \mathrm{~mm}$ 位離れた位置で曲げモーメントが零になることから, 地盤の すべり線がこの位置を通ると考えられる。

サイドパイルが長くなるほど, 緩んでいない領域に設置さ れる部分が長くなり, 土被りによる拘束を受ける領域が大き くなり, これによって負の曲げモーメントが大きくなると考 えられる。また, 長さが $260 \mathrm{~mm}$ 以上になると曲げモーメン 卜分布が変化せず, $260 \mathrm{~mm}$ 以遠での曲げモーメントが零と なることから, サイドパイルが有効な拘束を受ける領域は, 覆工から $100 \sim 260 \mathrm{~mm}$ の領域であると考えられる。

\section{2 .3 設置間隔がサイドパイルのカ学挙動に及ぼす影響}

図-27に，種々の間隔でサイドパイルを設置した場合，サ イドパイルに生じる曲げモーメントの分布を示す。曲げモー メントはいずれも同じ形状を示し, サイドパイルの左端から ほぼ 100 mm で曲げモーメントか零となる。このことから， 


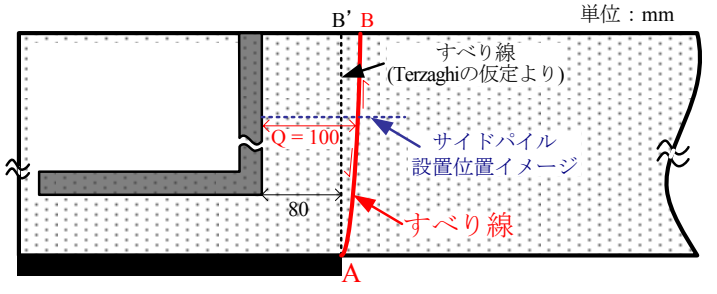

図-28 背面地山に生じる実際のすべり線（推定）

設置間隔にかかわらず，地盤のすべり線は左端から $100 \mathrm{~mm}$ の位置付近を通過し, サイドパイルとしては同等の力学挙動 を示すことが分かる。さらに, 設置間隔が狭くなるほど, 正 負の曲げモーメントいずれもその最大值が小さくなること が確認できる。

これは, サイドパイルに作用する地盤の拘束力は変化しな いことに対して, 設置間隔が狭くなると各パイルでの負担が 減少し，モーメントの絶対值が減少するものと考える。

\section{3 考察}

本節では，模型実験に対する数值解析の適用性を検証し， サイドパイルを設置する際, 地盤とサイドパイルの力学挙動 について検討を行った。

図-12 に示す Terzaghi の理論による仮定および解析結果に より，降下床の下降により図-28 に示す線 $\mathrm{AB}$ のようなす心゙ り線が形成されると考えられる。さらに, 解析結果から, 覆 工からこのすべり線までの位置はサイドパイルの効果を議 論する際に極めて重要であると考える。本研究では, この長 さを $\mathrm{Q}$ と表示し，これを用いて各值を標準化し，サイドパイ ルが地表面沈下抑制効果を発揮するメカニズムについて議 論を行う。

\section{6. まとめ}

模型実験および数值解析結果から考えられる, サイドパイ ルが地表面沈下抑制効果を発揮するメカニズムを図-29に示 す。

サイドパイルが地表面沈下抑制効果を発揮できる原因の ひとつとして, せん断補強効果が考えられる。サイドパイル を設置しない場合，降下床の下降により地山にせん断ひずみ が発生し，その集中する領域がすべり線となり地表面まで到 達する。サイドパイルを設置すると, そのす心゙り線がサイド パイルにより遮断され, 地表面まで到達するのを妨げる。す なわち, サイドパイルが, 覆工からすべり線までの距離 $\mathrm{Q} よ$ り長くなり, 図-29(a)に示すす心゙り線と交差することにより せん断補強効果が発揮されると考えられる。本研究での Q $100 \mathrm{~mm}$ である。

地山は, すべり線を境に, 覆工とすべり線の間は変位が大 きく, すべり線以遠の領域は比較的に変位が小さい。サイド パイルの設置により, 領域間の摩擦抵抗を増大させて変形を 拘束し，一種のはりを形成して支持すると考えられる。さら に，このはり効果により覆工の沈下も抑制され，覆工および

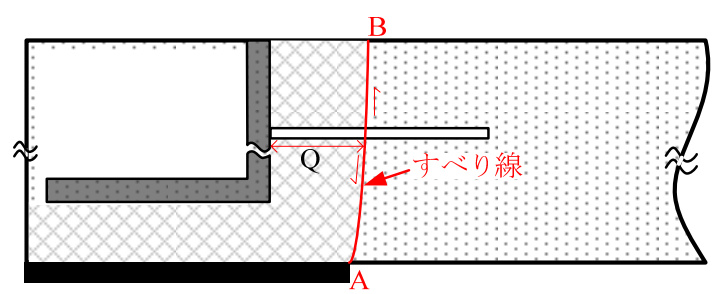

(a) せん断補強効果

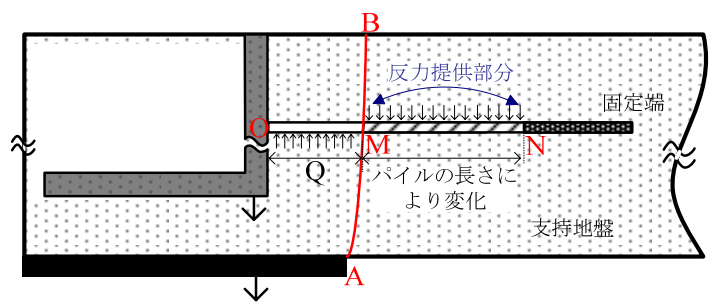

(b) 荷重再配分

図-29 サイドパイルの地表面沈下抑制メカニズム

降下床上部地盤に作用する荷重ははりにより覆工以遠領域 に分担される。すなわち, サイドパイルの設置により地盤に 生じる土圧が再配分され, 覆工直下および周辺地盤に生じる 荷重が,より健全な地盤(緩んでいない領域)に分担される。 これにより，覆工のさらなる変位が抑制される。

本研究では, サイドパイルの長さが $1.4 \mathrm{Q}(140 \mathrm{~mm})$ 以上 になると荷重が再配分され, 覆工および地表面の変位が抑制 される。さらに2.6 Q $(260 \mathrm{~mm})$ 以上になるとその効果が一 定になる結果が得られた。

サイドパイルの長さを選定する際, 覆工からすべり線まで の距離 Q は最も重要な参考パラメータとなる。これから, サ イドパイルを選定する際, まず数值解析などを通じて覆工周 辺地山に生じるすべり線の位置を算出する必要がある。さら に, 荷重の再配分効果が得られる最小長さおよびその効果が 頭うちになる上限長さを把握したうえ, 最小長さおよび $\mathrm{Q}$ と 上限長さの間で選定する。周辺地盤が均一, もしくは多層地 盤で水平方向に均一である場合, すべり線の発生位置は, 卜 ンネル掘削時トンネルに作用する緩み土圧を算出する際の Terzaghi の仮定により推測することができる ${ }^{17) 。 し か し な か ゙ ~}$ ら, 実現場の多くは地盤条件が均一でなく, この場合, トン ネルの掘削により生じるすべり線を推定するのは簡単でな い。これらに対しては, 周辺地盤について詳しく調查した上, 数值解析手法を用いた計算が考えられる。

設置間隔が狭いほど, 大きい地表面沈下抑制効果が得られ る。しかしながら，実際の NATM トンネルは $1 \mathrm{~m}$ あるいは $1.2 \mathrm{~m}$ 間隔で鋼製支保工を建て込むため，その設置できるサ イドパイルの本数が限られ, 設置間隔はほぼ施工条件により 決められる。本研究から, 設置間隔の設定について, サイド パイルの効果が相互にオーバーラップするような設定にす ることが望ましいと考える。結果として, 地盤を一体化して 保持することになる。本研究では, 隣接するサイドパイルの 影響領域がオーバーラップする最大設置閒隔は 0.6 Q $(60$ mm）であるという結論を得た。 
1) 北川 隆, 後藤光理, 磯谷篤実, 野城一栄, 松長 剛 : 低土被り 土砂地山トンネルの掘削時挙動の分析, トンネル工学報告集第 15 巻, pp.203-210, 2005.12 .

2) 山田浩幸, 加藤吉文, 大村修一, 久保田 聡 : 変位の大きい脆弱 地山における補助工法の設計と施工に関する一考察, トンネル工 学報告集, 第 17 巻, pp.51-58, 2007.11 .

3) 福島伸二, 望月美登志, 香川和夫, 横山章 : 土被りの浅い砂質地 山トンネルの補助工法に関する模型試験, 土木学会論文集, No.406/III-11, pp.79-86, 1989.6 .

4) 福島伸二, 望月美登志, 香川和夫 : 土かぶりの浅い砂質地山トン ネルにおけるボルト系補助工法の地山補強効果, 土と基礎, Vol.38, No.4, pp. 41-48, 1990.4.

5) 大川 孝, 横山治朗, 石原 久, 小島 亘: トンネル補助工法と してのパイプルーフ効果の計測と考察, 土木学会論文集, No.355/ VI-2, pp.100-107, 1985.3.

6) 北川隆, 後藤光理, 磯谷篤実, 菊本統, 木村亮, 岸田潔, 野城一 栄 : サイドパイルの沈下抑制効果に関する模型実験, 第 60 回土 木学会年次学術講演会, 講演概要集(CD-ROM), 2005.9.

7) 北川 隆, 後藤光理, 田村 武, 木村 亮, 岸田 潔 : サイドパ イルの沈下抑制効果に関する基礎的研究，トンネル工学報告集第 15 巻, pp.1-8, 2005.12.

8) 足立紀尚, 木村 亮, 岸田 潔, 小坂馨太, 坂山安男 : 3 次元降 下床実験によるトンネル交差部の力学挙動, 土木学会論文集, No.638/III-49, pp.285-299, 1999.12.
9) 菊本 統, 木村 亮, 岸田 梁, 足立紀尚：トンネル掘削時の力 学挙動に関する 3 次元降下床実験とその数值解析, 土木学会論文 集, No.750/III-65, pp.145-158，2003.12.

10) 足立紀尚, 木村 亮, 岸田 潔, 伊藤浩志 : 降下床実験による トンネル掘削過程を考慮したトンネルおよび周辺地盤の力学挙 動の解明, 土木学会論文集, No.694/III-57, pp.277-296, 2001.12.

11）村山朔郎, 松岡 元 : 砂質土中のトンネル土圧に関する基礎的 研究，土木学会論文集，No.187, pp.95-108，1971.3.

12) 社団法人 日本道路協会 : 道路橋示方書 - 同解説 I 共通編 $\cdot I V$ 下部構造編，社団法人 日本道路協会, pp.254-257, 2002.

13) Terzaghi, K. : Theoretical Soil Mechanics, John Wiley \& Sons, New York, pp.66-75, 1943.

14) Nakai, T. and Hinokio, M. : A Simple Elastoplastic Model for Normally and Over Consolidated Soils with Unified Material Parameters, Soils and Foundations, Vol. 44, No. 2, pp. 53-70, 2004.4.

15) Iizuka, A. and Ohta, H. : A Determination Procedure of Input Parameters in Elasto-Viscoplastic Finite Element Analysis, Soils and Foundations, Vol. 27, No. 3, pp. 71-87, 1987.9.

16) Zhang, F., Kimura, M., Nakai, T. and Hoshikawa, T. : Mechanical Behavior of Pile Foundations Subjected to Cyclic Lateral Loading Up to the Ultimate State, Soils and Foundations, Vol. 40, No. 5, pp. 1-17, 2000.10 .

17) 鉄道総合技術研究所編 : 鉄道構造物等設計標準・同解説 シー ルドトンネル, 丸善, pp.47-55, 2002.

(2008. 1.25 受付) 


\title{
Experimental study on effect of auxiliary methods for simultaneous settlement at subsurface and surface during shallow overburden tunnel excavation
}

\author{
Ying CUI ${ }^{1}$, Kiyoshi KISHIDA ${ }^{2}$ and Makoto KIMURA ${ }^{3}$ \\ 1 Doctoral student, Dept. of Urban and Environmental Engineering, Kyoto University \\ 2 Associate Professor, Dept. of Urban Management, Kyoto University \\ 3 Professor, Innovative Collaboration Center, Kyoto University
}

\begin{abstract}
Because of the topographic and linear condition, the applicability of excavating Shallow Overburden tunnel using NATM on soft ground is increasing. In the mentioned construction field, a phenomenon of equal settlements of the surface, crown and foot called phenomenon of accompanied settlement occurred, which had not been observed in the past. The mechanism of the phenomenon is not clearly understood, and preventing surface settlement has become a significant problem. In this study, the reinforcement effect of preventive system and effect of the length and spacing of preventive system has been clearly understood through experiment and FEM analysis. The results showed that preventive system is effective in preventing surface settlement, and the preventive system can prevent surface settlement by increasing the shear reinforcement and redistribution of load.
\end{abstract}

Key words: tunnel excavation, shallow overburden, settlement, modeling experiment, numerical simulation 